\title{
Paratuberculosis: The Hidden Killer of Small Ruminants
}

\author{
Sanaa M. Idris ${ }^{1,2}$, Kamal H. Eltom ${ }^{1, *}{ }^{\oplus}$, Julius B. Okuni ${ }^{3}{ }^{\circledR}$, Lonzy Ojok $^{3,4}$, Wisal A. Elmagzoub ${ }^{1,5}$, \\ Ahmed Abd El Wahed ${ }^{6, *(\mathbb{D}}$, ElSagad Eltayeb ${ }^{7} \mathbb{B}$ and Ahmed A. Gameel ${ }^{2}$
}

1 Department of Animal Health and Safety of Animal Products, Institute for Studies and Promotion of Animal Exports, University of Khartoum, Shambat 13314, Khartoum North, Sudan; sanaaidris15@gmail.com (S.M.I.); wisalelmagzoub@gmail.com (W.A.E.)

2 Department of Pathology, Faculty of Veterinary Medicine, University of Khartoum, Shambat 13314, Khartoum North, Sudan; aargameel@hotmail.com

3 College of Veterinary Medicine, Animal Resources and Biosecurity (COVAB), Makerere University, Kampala P.O. Box 7062, Uganda; jbokuni@gmail.com (J.B.O.); lonzyo@yahoo.com (L.O.)

4 Department of Pathology, Faculty of Medicine, Gulu University, Gulu P.O. Box 166, Uganda

5 Department of Biology and Biotechnology, College of Applied and Industrial Sciences, University of Bahri, Alkadaro 13311, Khartoum North, Sudan

6 Institute of Animal Hygiene and Veterinary Public Health, Faculty of Veterinary Medicine, University of Leipzig, An den, Tierkliniken 43, D-04103 Leipzig, Germany

7 Faculty of Medicine, Al Neelain University, Almogran 11111, Khartoum, Sudan; sagadgady@yahoo.com

* Correspondence: kamal@uofk.edu (K.H.E.); ahmed.abd_el_wahed@uni-Leipzig.de (A.A.E.W.); Tel.: +249-9102-899-16 (K.H.E.); +49-3419-738-153 (A.A.E.W.)

check for updates

Citation: Idris, S.M.; Eltom, K.H.; Okuni, J.B.; Ojok, L.; Elmagzoub, W.A.; El Wahed, A.A.; Eltayeb, E.; Gameel, A.A. Paratuberculosis: The Hidden Killer of Small Ruminants. Animals 2022, 12, 12. https:// doi.org/10.3390/ani12010012

Academic Editor: Valentina Virginia Ebani

Received: 13 October 2021

Accepted: 15 December 2021

Published: 21 December 2021

Publisher's Note: MDPI stays neutral with regard to jurisdictional claims in published maps and institutional affiliations.

Copyright: (C) 2021 by the authors. Licensee MDPI, Basel, Switzerland. This article is an open access article distributed under the terms and conditions of the Creative Commons Attribution (CC BY) license (https:// creativecommons.org/licenses/by/ $4.0 /)$.
Simple Summary: Paratuberculosis is a chronic disease of ruminants and many non-ruminant animals caused by the bacterium Mycobacterium avium subsp. paratuberculosis. Affected animals show diarrhoea, loss of weight, and decreased production performance with consequent economic losses. This bacterium has been detected in some humans suffering from a chronic intestinal disease known as Crohn's disease (CD) and, therefore, some scientists believe that CD is the human form of paratuberculosis. The disease in small ruminants has been reported in all continents, with goats being more susceptible than sheep. The clinical signs of the disease in goats are not so obvious as often do not show signs of diarrhoea, and the animal may die before being finally diagnosed. In Africa and many developing countries, paratuberculosis is described as a "neglected disease" particularly in small ruminants, which play a vital role in the livelihood of poor communities. This overview attempts to highlight the current research and gaps on this disease in small ruminants to draw more attention for further studies on diagnosis, prevention and control.

\footnotetext{
Abstract: Paratuberculosis (PTB) is a contagious and chronic enteric disease of ruminants and many non-ruminants caused by Mycobacterium avium subsp. paratuberculosis (MAP), and is characterised by diarrhoea and progressive emaciation with consequent serious economic losses due to death, early culling, and reduced productivity. In addition, indirect economic losses may arise from trade restrictions. Besides being a production limiting disease, PTB is a potential zoonosis; MAP has been isolated from Crohn's disease patients and was associated with other human diseases, such as rheumatoid arthritis, Hashimoto's thyroiditis, Type 1 diabetes, and multiple sclerosis. Paratuberculosis in sheep and goats may be globally distributed though information on the prevalence and economic impact in many developing countries seem to be scanty. Goats are more susceptible to infection than sheep and both species are likely to develop the clinical disease. Ingestion of feed and water contaminated with faeces of MAP-positive animals is the common route of infection, which then spreads horizontally and vertically. In African countries, PTB has been described as a "neglected disease", and in small ruminants, which support the livelihood of people in rural areas and poor communities, the disease was rarely reported. Prevention and control of small ruminants' PTB is difficult because diagnostic assays demonstrate poor sensitivity early in the disease process, in addition to the difficulties in identifying subclinically infected animals. Further studies are needed to provide more insight on molecular epidemiology, transmission, and impact on other animals or humans, socio-economic aspects, prevention and control of small ruminant PTB.
} 
Keywords: paratuberculosis; small ruminants; neglected disease

\section{Introduction}

Paratuberculosis (PTB) or Johne's disease (JD) is a chronic contagious disease of animals caused by Mycobacterium avium subsp. paratuberculosis (MAP). The disease was first described by Johne and Frothington in 1895 and first reported in sheep in Bosnia in 1908 [1]. Paratuberculosis affects mainly domestic and wild ruminants worldwide [2], also, it can affect many non-ruminant animals, such as camels, wild rabbits, pigs, horses, birds, and carnivores [3,4]. Furthermore, MAP has been detected in patients with Crohn's disease and was associated with other human diseases, such as rheumatoid arthritis, Hashimoto's thyroiditis, Type 1 diabetes, multiple sclerosis and autism, as presented by Garvey [5]. Thus, the disease can be considered a potential public health hazard [6].

Paratuberculosis can be suspected on clinical signs (intermittent diarrhoea and weight loss despite good appetite) and detection of acid-fast bacilli by microscopic examination in faeces, faecal or tissue culture, serological tests and molecular methods. Undetected subclinical infections greatly contribute to contamination of the environment and spread of the disease [7]. However, one of the main limitations of conducting prevalence studies on PTB is the difficulty in its diagnosis. A suitable, sensitive and confirmatory diagnostic test is a pre-requisite for such studies and hence for effective control programmes [8].

In Africa, PTB can be considered a neglected tropical disease because of little awareness about its occurrence in livestock populations, inadequate documentation and reporting; therefore, it was not considered in research and control programmes [9-11]. PTB is an OIE-listed disease (B) and should be reported to the World Organization for Animal Health (OIE) as indicated in the Terrestrial Animal Health Code [12].

The intestinal lesions of PTB cause protein leak, affect the gut microbiome and interfere with gut metabolism causing loss of nutrients and muscle wasting $[13,14]$. Therefore, as in cattle, PTB in small ruminants causes great economic losses in terms of low weight gains, reduced milk production, early culling and death $[15,16]$, in addition to costs related to diagnosis and disease control [17].

Small ruminants contribute significantly to the alleviation of poverty in poor communities in Africa and Asia through the provision of meat, milk and skins, and as a source of income through animal exports [18]; they are also a compact animal that costs little to feed and do not cost a lot to get their first offspring. This role would be greatly reduced by chronic diseases, such as PTB, in absence of good veterinary services and disease control programmes. However, in countries where sheep and goat farming are well established, production losses due to MAP infection seem to be better documented and economically evaluated [19]. In Australia, the average annual mortality rate due to PTB in 12 sheep flocks was reported to vary between 6.2 and $7.8 \%$, resulting in a 6.4 and $8.5 \%$ decrease of the average gross margin [20]. In some flocks, annual mortality approached $20 \%$ [21]. In New Zealand, annual losses estimates were US\$ 1.5 per MAP infected ewe of fine wool Merino-mainly due to $1.2-2.7 \%$ case fatality rate [19]. In the British sheep industry, the annual losses due to PTB were estimated in British Pounds from 0.5 to 16.5 million [22]. It was also reported that dairy sheep and goat farms in Italy suffered a decrease in profit efficiency from $84 \%$ to $64 \%$ due to MAP infection [23].

\section{Mycobacterium avium subsp. Paratuberculosis (MAP)}

Mycobacterium avium subsp. paratuberculosis is a slow growing, non-motile, aerobic, Gram-positive and acid-fast bacillus. Based on phenotypic characteristics (growth rate and pigmentation), two major strains of MAP have been identified: Type I/III and Type II, or MAP-S (sheep type) and MAP-C (cattle type), respectively [24]. Type I isolates are slow growers and mainly affect ovine hosts, while Type II isolates grow faster than type I and commonly affect cattle, in addition to deer, goats, sheep, and other ruminants [25]. 
MAP Type III isolates are intermediate growers and designated as a subgroup of the sheep or type strain S [24]. However, Type III strains have been isolated from sheep, goats, cattle and camels $[26,27]$. With the application of one of the genotyping methods, a third MAP type termed "bison" or "type B" for bison isolates was described [25], but further investigations using whole genome data of different MAP strains identified it as a subtype of type C strains [24]. These strains can be cultured from tissues and faeces of MAP infected animals. Cross transmission of strains between ruminant species can be indicated by typing methods [28]. This may be useful in evaluating the spread of MAP in different ruminant species kept under extensive systems where animal mingling is allowed (like Sudan and other African countries).

\section{Susceptibility to Infection with MAP}

Domestic ruminants (cattle, sheep and goat) are the commonly affected animals with MAP [29]. Susceptibility to MAP infection decreases with age; thus age together with the infecting dose and some other factors contribute to limiting the spread of MAP [30]. It is now known that not all animals exposed to MAP develop JD and some appear to clear the infection spontaneously. It is also suspected that some breeds of ruminants are more resistant to MAP infection than others; Merino sheep are reported to be more susceptible to PTB than Romneys [31]. In India, breeds of farm goats of Uttar Pradesh were found to be better adapted to the Indian Bison Type of MAP than those of farm goats in Rajasthan [32]. The study of Begg et al. [33] provides evidence of potential differential disease susceptibility between sheep breeds exposed to MAP infection. However, when compared, goats and cattle are more susceptible and are likely to develop clinical signs of MAP infection, while sheep are more resistant to the development of the clinical disease [34]. Sheep, goats and calves were found fairly comparable as infection models for MAP, though some differences in host responses to infection exist between them [35].

\section{Transmission of MAP}

MAP is mainly transmitted via ingestion of feed or water contaminated with manure. The infection is most common in young animals through ingestion of contaminated colostrum and milk of infected dams. The organism can also be transmitted from an infected pregnant dam to its foetus through the placenta [36]. A non-infected herd generally becomes exposed through herd expansion or replacement purchases of carrier animals [37].

\section{Clinical Signs of PTB}

Animals are usually infected during the first weeks of life, but they can become infected at any age. The clinical PTB in ovine and caprine is mostly observed in animals 2 to 4 years of age; the signs often occur soon after giving birth [38]. Stress factors may hasten the onset of clinical disease. However, clinical signs in sheep or goats are not a reliable indicator of the presence or absence of MAP infection [39]. Weight loss is the predominant clinical sign in infected sheep and goats. In sheep, the period of weight loss differs from one animal to another. Softening of the faeces or diarrhoea occurs only in $20 \%$ of the cases at the end stages of the disease [40]. Hypoproteinaemia with intermandibular oedema has been reported in sheep. Besides hypoproteinaemia, a decrease in serum calcium has been observed in sheep and cattle with clinical PTB [41]. Affected animals may show loss of appetite, dullness and rough coat with alopecia [42]. The classical clinical signs of PTB in goats are similar to those in sheep, but with no evidence of diarrhoea [43]. Sub clinically infected goats intermittently shed MAP in faeces up to one-year post-infection. During clinical disease, the animals become emaciated and develop antibodies against MAP, which are detectable in faeces. Advanced clinical disease is associated with progressive weight loss, fragile skin, poor hair coat, submandibular oedema, dehydration, anaemia, and depression [44]. 


\section{Prevalence and Distribution of PTB in Small Ruminants}

PTB has been reported in many European countries, such as Germany [45], Italy [23] and France [46], as well as in Oceania, Asian and African countries [47-49]. In the American continents, caprine PTB was reported in Missouri (USA) [50], Brazil [51], and Canada [52]. In New Zealand, PTB is endemic and widespread in sheep, dairy goats and other animals. Moreover, the disease is found in sheep, goats, dairy and beef cattle, alpaca, llama and deer in the parts of temperate south-eastern Australia [48]. It was noted that no studies have been conducted to provide valid estimates of the prevalence of PTB in sheep and goats in the United States, because of the lack of standardized firm diagnostic tests and funding for research in small ruminants [53]. In the Middle East and Africa, a few reports about PTB in small ruminants have been published. It was reported in sheep and goats in Sudan [54], Morocco [55], Saudi Arabia [56], Jordan [57], South Africa [47] and Egypt [58]. In Figure 1 countries with reported cases are presented; however, it is more likely to be globally distributed.

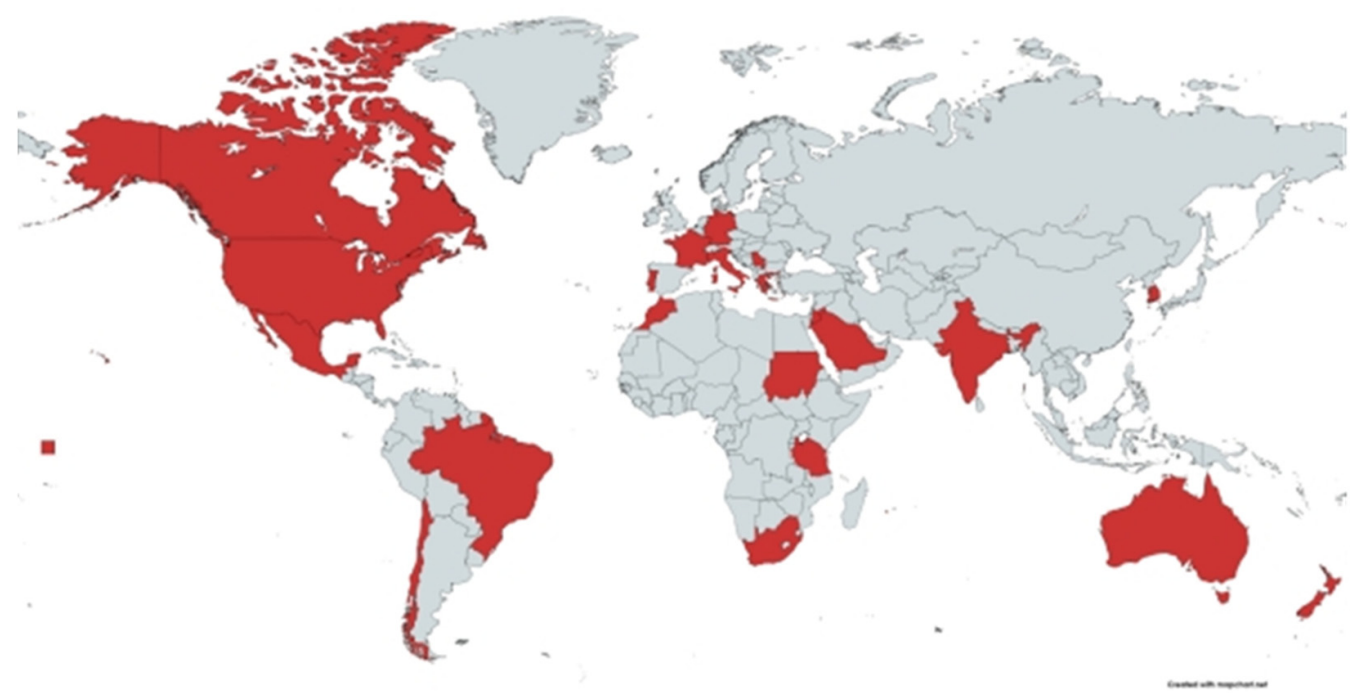

Figure 1. Countries with reported cases of paratuberculosis is small ruminants. The map was created from https:/ / mapchart.net/world.html.

\subsection{Prevalence of PTB in Goats at the Animal Level}

Prevalence rates of PTB in goats at the animal level vary from country to country and according to the test used. In Quebec (Canada) PTB was diagnosed in 29 out of 152 necropsied goats [52]; a prevalence of $4.3 \%$ has been reported in Latin American and Caribbean countries [59]. 17.1\% in Eastern Province, Saudi Arabia [56], 7.07\% and 15.86\% of apparent and true seroprevalence of MAP, respectively in the southwest of Iran [60].

\subsection{Flock-Level Prevalence of PTB in Goats}

The prevalence of PTB in goats at flock-level was recorded in many countries by using ELISA kits for MAP. Prevalence of $14.5 \%$ was reported in Italy [23], 83.0\% in Grenada, West Indies [61], $0.82 \%$ in Chile [62], $1.4 \%$ in Missouri, USA [50], 10.9\% in Arusha, Northern Tanzania [63], 16.8\% in Monteiro, Brazil [51], 3.7\% in Latin America and the Caribbean [59], 83\% in Ontario, Canada [42], 71\% in Germany [45], 3.7\%, and 3.9\% in Veracruz, Mexico [64,65], and $63.5 \%$ in North Gujarat (India) [66]. In the last study, prevalence rates of $28.0 \%, 7.14 \%$ and $12.0 \%$, were obtained for the same animals when screened by Z-N staining, faecal PCR and blood PCR, respectively [66]. In South Korea, the prevalences of $0.8 \%$ and $0.6 \%$ were obtained using ELISA and faecal culture, respectively [67]. 


\subsection{Prevalence of PTB in Sheep at Animal Level}

Indirect and conventional tests were used to estimate the prevalence rate of PTB in sheep at the animal level. In Quebec (Canada), 3\% prevalence was reported based on characteristic histological lesions in the terminal ileum, ileocecal lymph node and/or ileocecal valve [68]. In the Western and Eastern Cape provinces (South Africa), where the AGID assay was used to identify 52 infected farms, $5 \%$ of the sheep population was infected [47]. ELISA test was used in many studies and prevalence rates of $2.3 \%, 14 \%, 3.3 \%$, $3.25 \%$ and $15.37 \%$ in Grenada, Germany, Backa and Srem regions (Serbia), Tunisia and Khuzestan Province of Iran respectively, were reported [45,60,61,69,70]. In Latin America and the Caribbean, the prevalence was $16 \%$ [59].

\subsection{Flock-Level Prevalence of PTB in Sheep}

The prevalence rate of PTB using ELISA kits was 3\% in each of the Western Cape Province, South Africa and Apulia, southern Italy [23,47], 65\% in Germany [45] and 73.7\% in Marche region, central Italy [71]. In the northeast of Portugal, a prevalence of $42.7 \%$ was detected in 64 flocks by PCR [72]. Valid estimates of the prevalence of MAP infection at the animal and herd levels are important to determine whether the disease warrants interventions to mitigate its negative impact on herd profitability.

Generally, the prevalence of PTB in small ruminants at the animal level estimated by seroprevalence in reporting countries is very low when compared with cattle and buffalo. Moreover, in these large animals, studies that targeted diarrhoeic animals showed a very high seroprevalence of the disease [73]; however, diarrhoea in small ruminants is not a prominent sign of the disease.

As prevalence studies target estimation of the disease either at animal level or herd/flock level or at both, detection of the disease in one animal indicates its occurrence in many others within the herd/flock. On the other hand, prevalence estimates at the herd/flock level are important for knowledge on the disease distribution.

\section{Pathogenesis of PTB}

The pathogenesis of PTB infection in all animals is the same. Neonates and juvenile animals are infected mainly via the oral route from contaminated colostrum and milk.

Transmission may occur by the consumption of milk and colostrum from infected dams [74]. After ingestion, MAP enters the intestinal tract, becomes translocated through the intestinal mucosa mediated by M-cells overlying Peyer's patches. The bacteria specifically invade the sub-epithelial macrophages, slowly replicate and stimulate the cell mediated immune (CMI) response-initial $\mathrm{T}$ cell response [75]. The humoral response is not elicited at the early stages of MAP infection, but later when the CMI response fades and the bacteria are released from macrophages, a strong antibody response is initiated [76]; this usually occurs in advanced clinical cases of PTB. A relationship between immunological responses to MAP and PTB pathology was observed in affected animals, from which two forms were described: the multibacillary and the paucibacillary. In general, the multibacillary (or lepromatous) form is observed when the humoral response becomes predominant and is demonstrated by granulomatous enteritis [77]. This form is more likely to be found in sheep than in other animal species [78]. The paucibacillary (or tuberculoid) form is associated with a strong CMI response and characterized by lymphocytic infiltration in the lamina propria, with few or no visible mycobacteria $[77,79,80]$; this form has been observed in goats $[78,81]$. Therefore, the animal responses to any diagnostic test will depend upon the stage of the disease.

\section{Pathologic Changes of PTB}

\subsection{Pathologic Changes of PTB in Sheep}

The gross lesions of PTB in sheep involve thickening of the intestines at various locations with multiple degrees of mucosal corrugation, predominantly near the ileocaecal junction $[57,82-85]$. Changes in the caecum and colon are less severe than in the 
terminal ileum $[40,86]$. Mesenteric and ileocaecal lymph nodes (MLN and ICLN) are enlarged in up to half of cases and are usually oedematous [77,87]. The histopathological characteristics observed in sheep consist of granulomatous enteritis with marked cellular infiltrate composed of epithelioid, lymphocyte, macrophage and giant cells with acid-fast bacilli [85-87]. Villous atrophy, necrosis and hyperplasia of Peyer's patches have been reported by Coelho et al. [87]. Histopathological changes of MLN and ICLN include infiltration of epithelioid cells and macrophages containing acid-fast organisms [82,87]; also, occasionally, giant cells and foci of caseous necrosis can be seen [88].

\subsection{Pathologic Changes of PTB in Goats}

Thickening and folding of the intestinal wall, corrugation, granular mucosa, serous atrophy of fat and thickening of mesenteric lymphatic vessels were seen grossly. Oedematous enlargement and occasionally calcium deposits were seen in the MLN [89,90]. Greig [91] reported the histopathology of PTB in goats at two stages: infiltration of lymphocytes, plasma cells and macrophages in the lamina propria at the early stages of the disease, and in the late severe stages, macrophages and giant cells can be found in the submucosa and muscle layers. Acid-fast bacilli may be seen in significant numbers. Histopathological lesions were classified into four types (I, II, III and IV) by Hailat et al. [57] and Thakur et al. [90], depending on the type and density of cellular infiltrates (lymphocytes, macrophages and epithelioid cells) in the small intestines and MLN. Lesions are considered grade I if a large number of lymphocytes with very few macrophages and epithelioid cells are found. Infiltration of lymphocytes in a lesser amount than in grade I with some macrophages and epithelioid cells (more than in grade I) are considered as grade II. Abundant numbers of epithelioid cells and macrophages with a small number of lymphocytes to form micro-granuloma are considered as grade III. Grade IV is considered when lesions have few lymphocytes and large amount of epithelioid cells with proliferation of Peyer's patches and formation of micro-granuloma with giant cells [83]. In goats with advanced PTB, granulomatous lesions were also noted in the liver and lungs [92]. Derakhshandeh et al. [89] reported the diffuse multibacillary lesions, characterized by diffuse granulomatous enteritis and lymphadenitis showing large numbers of epithelioid macrophages in the intestinal lamina propria and cortex of lymph nodes. Lymphangitis and lymphangiectasia in the submucosa and caseous necrosis and calcification in lymph nodes were also noticed.

\section{Diagnosis of PTB}

Diagnosis of paratuberculosis is based on clinical signs, postmortem lesions, and laboratory confirmation that involves tests for direct detection of the bacteria, such as demonstration of MAP in clinical samples by microscopy, MAP isolation by culturing and detection of the DNA of MAP. The indirect tests as diagnostic assays of MAP infection are based on detection of the host immune response to infection, such as delayed-type hypersensitivity (DTH), interferon assay, enzyme-linked immunosorbent assay (ELISA), agar gel immunodiffusion (AGID) and complement fixation test (CFT) $[93,94]$. Histopathological analysis is considered a conventional method [95]. Due to variation in PTB presentation from affected to infectious, to an infected animal (termed as "target conditions" or "case definitions") that have been described as standardized diagnostic criteria for clinical intervention $[96,97]$, sensitivity and specificity of diagnostic techniques to confirm these case definitions vary accordingly. However, a screening technique to confirm the stages of PTB in infected animals is lacking [98]. Therefore, the World Organization for Animal Health (OIE) recommended the evaluation of a diagnostic test after a statement of the purpose of the test [99].

\subsection{Microscopic Examination}

Direct microscopy is used as a rapid technique to detect acid-fast bacilli after preparation of faecal samples and staining by the Ziehl Neelsen (ZN) technique [66]. The sensitivity and specificity of $Z N$ staining are low with difficulties in differentiation between MAP and 
other acid-fast bacilli. In one of the comparative studies that show the low sensitivity of ZN, Kumthekar et al. [61] detected acid-fast bacilli by ZN staining in only 4 out of 12 samples of ELISA-positive small ruminants, indicating low sensitivity of ZN staining. However, $\mathrm{ZN}$ staining is the simplest, fastest, and most economical method of diagnosis and can be used for the initial screening of MAP [100].

\subsection{Culture Methods}

Diagnosis of PTB by isolating MAP by culture is the "gold standard" which is considered confirmation method [101]. Moreover, isolation of MAP is difficult due to intermittent shedding of the bacteria and the low number of bacilli in faeces and tissues, respectively [102,103]. Furthermore, MAP is a slow growing organism, which requires several weeks to months for growth in laboratory media. However, incubation of samples with antibiotics before culturing to prevent overgrowth by other faster growing bacteria can lead to killing some MAP bacilli in samples with a low level of bacteria. Therefore, MAP culture from faeces and tissue samples is less sensitive compared with molecular methods and histopathology of lesions to confirm the PTB in animals that were diagnosed clinically [87]. Prior to 1998, the available culture media were not appropriate to support the growth and detection of MAP sheep strains. Radiometric culture has been reported as more sensitive than histopathology and solid media when was used to detect MAP infection in sheep, goats and cattle. In liquid and solid media, the egg yolk and mycobactin J are considered essential additives for the growth of ovine strains of MAP [104,105]. Culture of MAP from goats on Löwenstein-Jensen, Herrold's egg yolk medium (HEYM) with and without sodium pyruvate and Middlebrook 7H11 containing mycobactin J has been used [106]. Goats can be infected by various MAP strains and, therefore, different media and an incubation period of up to 6 months should be expected before getting detectable growth of MAP in culture.

\subsection{Molecular Assays}

Molecular assays are useful techniques in the diagnosis of PTB in suspected animals' faeces and blood, as they improve the sensitivity of detection of MAP by targeting its genome. However, there is potential for cross-reactions or inhibition from biological substances for these assays. MAP genome in the faecal and blood samples is detected in extracted DNA by PCR amplification of the insertion sequence 900 (IS900) element [66,87]. Sonawane and Tripathi [107] found 251 gene PCR is better than IS900 in the detection of MAP from the tissues. Additionally, PCR was found to be more sensitive than a histopathological examination of 66 suspected goat carcasses with PTB [89], while nine (13.63\%) carcasses were positive for MAP in both histopathology and PCR, eight were positive in PCR without histopathological lesions related to PTB. The insertion sequence 1311 (IS1311) has also been used in nested PCR to amplify the MAP DNA of caprine tissue isolates [108]. Multiplex PCR based on the IS900, IS901, IS1245 and the dnaJ gene has been developed to overcome false-positive results arising from the presence of IS900-like insertion sequences in other mycobacteria. However, because of reagent interference and primer dimers, the sensitivity of this test is still low [94,109]. A more sensitive and specific real-time PCR assay was developed for detecting MAP, based on the combination of IS900 and 251 genomic loci, which was identified as MAP-specific with a set of specific primers and probe, as described by Rajeev et al. [110]. In other studies, an F57-based real-time PCR system was used to detect MAP in milk or cheeses [111,112]. Moreover, a loop-mediated isothermal amplification assay (LAMP) targeting ISMap02 was used as a rapid and sensitive detection tool for MAP in small ruminants [113].

\subsection{Serologic Tests}

The serologic tests used as diagnostic techniques for PTB in small ruminants include AGID, CFT and the ELISA. These tests are very important in small ruminants, in which the culture of faeces has low sensitivity and is costly [114]. Goats, in comparison with sheep, 
have strong and early antibody responses suggesting that current serological tests may be more sensitive in this species [115].

\subsubsection{Enzyme-Linked Immunosorbent Assays (ELSIA)}

The sensitivities and the specificities of ELISA assays to detect PTB in small ruminants are in the range $16-100 \%$ and $79-100 \%$, respectively. Therefore, the variations in the sensitivity and specificity of ELISA assays should be interpreted with attention [97], despite these variations, the ELISA has been used in domestic animals as a screening test [116]. However, an indigenous ELISA kit was found superior to commercial ELISA kits in the detection of PTB in sheep and goats in India [117]. Moreover, milk ELISAs for PTB in goats, relative to faecal culture was found to be a cost-effective and accurate alternative [62] Additionally, ELISA has been proven useful for the detection of ovine PTB with estimated specificity of 98.2 to $99.5 \%$ and sensitivity of 35 to $54 \%$ [118].

\subsubsection{Agar Gel Immuno-Diffusion (AGID) Test}

The AGID has been reported as a successful screening method in control programmes of PTB in cattle, sheep and goats [100]. In earlier studies, its specificity was reported as $100 \%$. Moreover, the test showed higher sensitivity and specificity than ELISAs when it was used in small ruminants in New Zealand and Australia [118-120] and was reported as better than the absorbed ELISA in detecting MAP-infected sheep with poor body condition [118]. However, in later reports, the sensitivity of AGID was found to be less than that of the ELISA [121,122]. The specificity and sensitivity of AGID measured against ELISA were $99 \%$ to $100 \%$ (95\% CI) and 38\% to 56\% (95\% CI), respectively [118]. Kumthekar et al. [61] found that out of 12 ELISA-positive small ruminants, only five animals were positive when they were tested by a commercial AGID assay.

\subsubsection{The Complement Fixation Test (CFT)}

CFT is used for the screening of PTB in suspected animals $[123,124]$. The sensitivity of the CFT has been reported in a range of 10 to $90 \%$ [125-127]. The specificity of CFT was less than AGID and ELISA as reported by Singh et al. [128]. However, in Japan, the CFT is requested by importing countries and is used for diagnosis in small ruminants (sheep and goats) combined with a Johnin skin test [19]. Moreover, the confirmation of the clinical diagnosis of PTB by CFT is recommended in Europe, although it is considered less accurate than the ELISA with respect to sensitivity and specificity [129]. Diagnostic techniques used for PTB in small ruminants from 2012 to 2020 are summarized in Table 1. 
Table 1. Diagnosis of paratuberculosis in small ruminants using different techniques (2012-2020).

\begin{tabular}{|c|c|c|c|c|c|c|c|c|c|}
\hline $\begin{array}{l}\text { No. of } \\
\text { Studies }\end{array}$ & $\begin{array}{c}\text { Total No. of } \\
\text { Animals or } \\
\text { Samples }\end{array}$ & $\begin{array}{c}\text { Smears from } \\
\text { Faeces or } \\
\text { Tissue/Inclusion } \\
\text { Criteria }\end{array}$ & $\begin{array}{l}\text { PCR/Inclusion } \\
\text { Criteria }\end{array}$ & Real-Time PCR & ELISA & $\begin{array}{l}\text { AGID/Inclusion } \\
\text { Criteria }\end{array}$ & Culture & Histopathology & Ref. \\
\hline 1 & $\begin{array}{l}479 \text { sheep } \\
260 \text { goats }\end{array}$ & 4/5 AGID +ve & & & $\begin{array}{c}11(2.3 \%) \text { sheep } \\
1(0 \%) \text { goat }\end{array}$ & 5/12 ELISA +ve & & $\begin{array}{c}2 \text { sheep }+ \text { ve in } 3 \\
\text { tests }\end{array}$ & [61] \\
\hline 2 & 219 goats & $9.2 \%(7 / 76)$ & $12.5 \%(5 / 40)$ & & $43.3 \%(95 / 219)$ & $10 \%(24 / 219)$ & & & [130] \\
\hline 3 & 200 sera from goats & $\begin{array}{c}14 / 50(28.0 \%) \\
\text { (strong reactors in } \\
\text { ELISA) }\end{array}$ & $\begin{array}{c}1 / 14(7.14 \%)+v e \\
\text { faecal smears and } \\
6 / 50(12.0 \%) \text { strong } \\
\text { ELISA +ve. }\end{array}$ & & $63.5 \%$ & & & & [66] \\
\hline 4 & 30 sheep & & $\begin{array}{c}4(13.3 \%) \text { faeces, } 19 \\
(63.3 \%) \text { tissues, } 7 \\
(23.3 \%) \text { blood }\end{array}$ & & $3(10.0 \%)$ & & $\begin{array}{c}2(6.7 \%) \text { faeces, } 6 \\
(20.0 \%) \text { tissues }\end{array}$ & $21(70.0 \%)$ & [87] \\
\hline 5 & $\begin{array}{l}66 \text { slaughtered } \\
\text { goats }\end{array}$ & & $9(13.63 \%)$ tissue & & & & & $9(13.63 \%)$ & [89] \\
\hline 6 & $\begin{array}{l}130(8.7 \%) \\
\text { suspected small } \\
\text { ruminants }\end{array}$ & $62(47.7 \%)$ faeces & & $\begin{array}{c}25(65.8 \%) / 38 \\
+ \text { ve faecal } \\
\text { smears }\end{array}$ & & & & & [85] \\
\hline 7 & 192 goats & & & & $\begin{array}{l}21(10.9 \% \\
7.3-16.1 \%)\end{array}$ & & & & [63] \\
\hline 8 & $\begin{array}{l}168 \text { sheep (farm 1), } \\
112 \text { sheep (farm 2) }\end{array}$ & $\begin{array}{c}30(60.0 \%) \\
5(10.0 \%)\end{array}$ & $\begin{array}{l}24(35.2 \%) \\
6(50.0 \%)\end{array}$ & & $\begin{array}{c}38(76.0 \%) \\
7(14.0 \%)\end{array}$ & & & & [131] \\
\hline 9 & $\begin{array}{c}121 \text { serum samples } \\
16 \text { pooled faecal } \\
\text { samples }\end{array}$ & $2 / 16$ faecal samples & $\begin{array}{c}11 / 23(9 \%) \text { ELISA } \\
\text { strong +ve }\end{array}$ & & & $\begin{array}{c}23 / 121 \\
(19.01 \%) / \text { strong } \\
\text { +ve } 85 / 121 \\
(70.25 \%)+\text { ve }\end{array}$ & & & [132] \\
\hline
\end{tabular}




\section{Treatment, Control and Prevention}

Successful treatment of PTB has not been reported in infected animals [124]; however, control programmes for dairy cattle can be applied to dairy goats and sheep. Changes in management practices in order to reduce the transmission of MAP as well as the test-andcull method to eliminate shedding of MAP and using vaccination to increase resistance to infection, all these methods had been reported as the main approaches to control and eradicate PTB $[19,133,134]$. In addition, biosecurity is the essential approach in uninfected animals for reducing both within-farm and between-farms spread of infection [94].

\subsection{Changes of Management Practices}

To cut off the transmission of MAP, good management practices are an important approach for controlling ovine/caprine PTB, especially in small flocks/herds. These management practices involve feeding uncontaminated colostrum and milk replacement products, rearing young stock separately from the adults, separating offspring from dams, minimizing the contact between infected adult goats, sheep and others, avoiding exposure to potentially infected adult animals, their manure and the contaminated environment were recognized as control measures of PTB within-farms [42,135,136]. Producer knowledge, diligence and investments have been reported as essential elements in the effectiveness of this approach through improving the biosecurity practices [137].

\subsection{Test-and-Cull}

The effectiveness and repetition of diagnostic techniques are considered the main issue for test and cull strategies to identify the early infection of MAP in animals, particularly before their incipience of faecal shedding [138]. Therefore, the limited application of this strategy in sheep and goats is attributed to relation between the individual value of animals and the high cost of diagnostic tests with variations in their sensitivities [137]. Moreover, diagnostic tests are critical issues in control programmes of PTB. As the timeinterval between the infections and the animal shows clinical signs and/or gives positive results in diagnostics tests is very long, the test and cull approach would be difficult [134] However, the combination of vaccination with 'test and cull' was found to be economical as well as a more effective strategy to control PTB in various herds of goats, buffaloes and cattle $[139,140]$.

\subsection{Vaccination}

Paratuberculosis vaccine is commonly applied in small ruminants to reduce the clinical disease because vaccines reduce the shedding of MAP by infected animals and lower the severity of clinical cases $[53,141]$. Vaccination is cost-effective strategy compared with other control strategies $[134,142,143]$. Many countries have applied the strategy of vaccination for sheep successfully $[133,142]$. However, vaccination is not considered the best option as a control measure and is even prohibited in some countries because of interference with the skin test for diagnosis of tuberculosis. Luckily, new promising approaches to overcome this interference have been applied successfully by using proteinic and peptidic cocktails in skin tests instead of traditional test reagents [144]. On the other hand, in a number of countries, such as Australia [145], New Zealand [146], Spain [147], India [148] and The Netherlands [149], vaccination as a management measure to control paratuberculosis has been used.

It is recommended that vaccination of small ruminants against PTB be done in very young animals to prevent interference with the diagnosis of tuberculosis. Vaccination trials in Australian sheep indicated 8 months as the age threshold for vaccination efficacy [150]. Persistence of antibodies for up to 42 months post-vaccination was reported, but infection from the environment could not be ruled out to have a booster effect leading to this long persistence [151]. Dairy goats in infected herds in The Netherlands are commonly vaccinated once during the first months of life [149]. 
Currently, the vaccines in use against PTB include live (non-attenuated and attenuated) and killed whole cell vaccines, as well as subunit vaccines which have been used in a few cases with less degree of protection $[134,152,153]$. Based on efficacy, both the inactivated (killed) vaccines and attenuated vaccines were equally effective [154]. However, many countries do not prefer live vaccines because of the partial protection that might be provided by reducing the clinical cases, not the eradication of infection with frequently diminishing immunity of vaccinated animals when are sold to other herds; also, perhaps because of public health issue by infecting humans [134].

\subsection{Selective Breeding}

Evidence of breed susceptibility to PTB has been reported as mentioned earlier in this review. Therefore, the role of host genetics can be an alternative approach to control chronic diseases like JD [155,156]. Breeding for disease resistance would be an effective means for controlling PTB in domestic ruminants.

\section{Research Gaps}

Effects of PTB of small ruminants on other animals or humans and its socioeconomics received no attention; molecular epidemiology of MAP and its dynamics of transmission, in addition to the role of the gut microbiome in susceptibility and resistance to MAP infection have not been yet addressed in small ruminants. Studies evaluating strategies for controlling PTB in small ruminants, such as test-and-cull and/or vaccination are scanty and limited; and evaluation of pooled samples in screening the disease with different diagnostic tests is yet to be addressed.

\section{Conclusions}

A few studies about PTB in small ruminants have been published, especially from Africa and the Middle East. Therefore, prevention and control programmes for PTB in small ruminants have not been established in many countries. Further studies investigating the prevalence of PTB in small ruminants can provide important insights into setup the first step in prevention and control. Increasing public awareness about the possible effects of MAP on human health requires intensive work.

Small ruminants, especially goats, in developing countries play an important role in maintaining the livelihood and food security of people in rural areas, in addition to their contribution to the national economies of many countries. Difficulties in identifying subclinical cases and limitations of available diagnostics, combined with the negligence of the disease make PTB in small ruminants a hidden killer in most cases.

Author Contributions: Conceptualization, A.A.G. and K.H.E.; writing-original draft preparation, S.M.I.; writing-review and editing, A.A.G., W.A.E., K.H.E., J.B.O., L.O., A.A.E.W. and E.E.; supervision, A.A.G. and K.H.E.; project administration, K.H.E. and A.A.E.W.; funding acquisition, A.A.E.W. All authors have read and agreed to the published version of the manuscript.

Funding: This research was funded by the German Research Foundation (DFG), grant number 404935781.

Conflicts of Interest: The authors declare no conflict of interest. The funders had no role in the design of the study; in the collection, analyses, or interpretation of data; in the writing of the manuscript, or in the decision to publish the results.its economic importance for livestock industry and socio-economic role in poor communities. There is also increasing public awareness about the possible effects of MAP on human health. Important gaps include; studies on effects of paratuberculosis of small ruminants on other animals or humans, socioeconomics, molecular epidemiology of MAP in small ruminants and their dynamics of transmission were not addressed. 


\section{References}

1. West, D.M.; Bruère, A.N.; Ridler, A.L. The Sheep: Health, Disease and Production, 3rd ed.; Veterinary Continuing Education, Massey University: Palmerston North, New Zealnd, 2009.

2. Cunha, V.M.; Rosalino, L.M.; Leao, C.; Bandeira, V.; Fonseca, C.; Botelho, A.; Reis, A.C. Ecological Drivers of Mycobacterium avium Subsp. Paratuberculosis Detection in Mongoose (Herpestes Ichneumon) Using Is900 as Proxy. Sci. Rep. 2020, 10, 860. [CrossRef] [PubMed]

3. Curlik, J.; Lazar, P.; Iglodyova, A.; Barbusinova, E.; Smiga, L.; Novotny, J.; Mojzisova, J.; Ondrejkova, A.; Hromada, R.; Konjevic, D.; et al. Detection of Mycobacterium avium Subsp. Paratuberculosis in Slovakian Wildlife. Pol. J. Vet. Sci. 2020, $23,529-535$.

4. Stanitznig, A.; Khol, J.L.; Lambacher, B.; Franz, S.; Wittek, T.; Kralik, P.; Slana, I.; Vasickova, P. Prevalence of Mycobacterium avium Subspecies Paratuberculosis and Hepatitis E in New World Camelids in Austria. Vet. Rec. 2017, 181, 46. [CrossRef] [PubMed]

5. Garvey, M. Mycobacterium avium Subspecies Paratuberculosis: A Possible Causative Agent in Human Morbidity and Risk to Public Health Safety. Open Vet. J. 2018, 8, 172-181. [CrossRef] [PubMed]

6. Bharathy, S.; Gunaseelan, L.; Porteen, K. Exploring the Potential Hazard of Mycobacterium avium Subspecies Paratuberculosis as a Cause for Crohn's Disease. Vet. World 2017, 10, 457-460. [CrossRef] [PubMed]

7. Garvey, M. Mycobacterium avium Paratuberculosis: A Disease Burden on the Dairy Industry. Animals 2020, 10, 1773. [CrossRef]

8. Singh, S.; Dhakal, I.P.; Singh, U.M.; Devkota, B.N. Current Diagnostic Techniques of Mycobacterium avium Subsp. Paratuberculosis in Domestic Ruminants. J. Agric. For. Univ. 2018, 2, 23-34.

9. Okuni, J.B. Occurence of Paratuberculosis in African Countries: A Review. J. Vet. Adv. 2013, 3, 1-8.

10. Okuni, J.B.; Hansen, S.; Eltom, K.H.; Eltayeb, E.; Amanzada, A.; Omega, J.A.; Czerny, C.P.; el Wahed, A.A.; Ojok, L. Paratuberculosis: A Potential Zoonosis and a Neglected Disease in Africa. Microorganisms 2020, 8, 1007. [CrossRef] [PubMed]

11. Omega, J.A.; Musalia, L.M.; Kuria, J.K. Knowledge, Attitude and Practices Towards Paratuberculosis in Cattle and Sheep in Kericho County and Konoin Sub-County, Kenya. Afr. J. Educ. Sci. Technol. 2019, 5, 76-86.

12. OIE. Terrestrial Animal Health Code, 28th ed.; Volume 1, Disease, Infections and Infestations Listed by the OIE; World Organization for Animal Health: Paris, France, 2019.

13. Matthews, C.; Cotter, P.D.; O’Mahony, J. Map, Johne's Disease and the Microbiome; Current Knowledge and Future Considerations. Anim. Microbiome. 2021, 3, 34. [CrossRef]

14. Cani, P.D.; Bibiloni, R.; Knauf, C.; Waget, A.; Neyrinck, A.M.; Delzenne, N.M.; Burcelin, R. Changes in Gut Microbiota Control Metabolic Endotoxemia-Induced Inflammation in High-Fat Diet-Induced Obesity and Diabetes in Mice. Diabetes 2008, 57, 1470-1481. [CrossRef]

15. Rieger, A.; Meylan, M.; Hauser, C.; Knubben-Schweizer, G. Meta-Analysis to Estimate the Economic Losses Caused by Reduced Milk Yield and Reproductive Performance Associated with Bovine Paratuberculosis in Switzerland. Schweiz. Arch. Tierheilkd. 2021, 164, 737-751. [CrossRef]

16. Rasmussen, P.; Barkema, H.W.; Mason, S.; Beaulieu, E.; Hall, D.C. Economic Losses Due to Johne's Disease (Paratuberculosis) in Dairy Cattle. J. Dairy Sci. 2021, 104, 3123-3143. [CrossRef] [PubMed]

17. Mendes, S.; Boinas, F.; Albuquerque, T.; Fernandes, L.; Afonso, A.; Amado, A. Epidemiological Studies on Paratuberculosis in Small Ruminants in Portugal. Epidémiol. Santé Anim. 2004, 45, 61-71.

18. Devendra, C. Small Ruminants: Potential Value and Contribution to Sustainable Development. Outlook Agric. 1994, $23,97-103$. [CrossRef]

19. Whittington, R.; Donat, K.; Weber, M.F.; Kelton, D.; Nielsen, S.S.; Eisenberg, S.; Arrigoni, N.; Juste, R.; Saez, J.L.; Dhand, N.; et al. Control of Paratuberculosis: Who, Why and How. A Review of 48 Countries. BMC Vet. Res. 2019, 15, 198. [CrossRef] [PubMed]

20. Bush, R.D.; Windsor, P.A.; Toribio, J.A. Losses of Adult Sheep Due to Ovine Johne's Disease in 12 Infected Flocks over a 3-Year Period. Aust. Vet. J. 2006, 84, 246-253. [CrossRef] [PubMed]

21. Windsor, P.A. Managing Control Programs for Ovine Caseous Lymphadenitis and Paratuberculosis in Australia, and the Need for Persistent Vaccination. Vet. Med. 2014, 5, 11-22. [CrossRef]

22. Ashworth, S.; Gunn, G.J. Losses Associated with Paratuberculosis in Sheep. In Assessment of Surveillance and Control of Johne's Disease in Farm Animals in Gb; Galdow, G., Gunn, G.J., Eds.; SAC Veterinary Division: Edinburgh, UK, $2001 ;$ pp. 103-115.

23. Sardaro, R.; Pieragostini, E.; Rubino, G.; Petazzi, F. Impact of Mycobacterium avium Subspecies Paratuberculosis on Profit Efficiency in Semi-Extensive Dairy Sheep and Goat Farms of Apulia, Southern Italy. Prev. Vet. Med. 2017, 136, 56-64. [CrossRef] [PubMed]

24. Bryant, J.M.; Thibault, V.C.; Smith, D.G.; McLuckie, J.; Heron, I.; Sevilla, I.A.; Biet, F.; Harris, S.R.; Maskell, D.J.; Bentley, S.D.; et al. Phylogenomic Exploration of the Relationships between Strains of Mycobacterium avium Subspecies Paratuberculosis. BMC Genom. 2016, 17, 79. [CrossRef] [PubMed]

25. Fawzy, A.; Zschock, M.; Ewers, C.; Eisenberg, T. Genotyping Methods and Molecular Epidemiology of Mycobacterium avium Subsp. Paratuberculosis (Map). Int. J. Vet. Sci. Med. 2018, 6, 258-264. [CrossRef] [PubMed]

26. de Juan, L.; Mateos, A.; Dominguez, L.; Sharp, J.M.; Stevenson, K. Genetic Diversity of Mycobacterium avium Subspecies Paratuberculosis Isolates from Goats Detected by Pulsed-Field Gel Electrophoresis. Vet. Microbiol. 2005, 106, 249-257. [CrossRef] [PubMed]

27. Ghosh, P.; Hsu, C.; Alyamani, E.J.; Shehata, M.M.; Al-Dubaib, M.A.; Al-Naeem, A.; Hashad, M.; Mahmoud, O.M.; Alharbi, K.B.; Al-Busadah, K.; et al. Genome-Wide Analysis of the Emerging Infection with Mycobacterium avium Subspecies Paratuberculosis in the Arabian Camels (Camelus Dromedarius). PLoS ONE 2012, 7, e31947. [CrossRef] [PubMed] 
28. Mizzi, R.; Timms, V.J.; Price-Carter, M.L.; Gautam, M.; Whittington, R.; Heuer, C.; Biggs, P.J.; Plain, K.M. Comparative Genomics of Mycobacterium avium Subspecies Paratuberculosis Sheep Strains. Front. Vet. Sci. 2021, 8, 637637. [CrossRef]

29. Sallam, A.M.; Zare, Y.; Alpay, F.; Shook, G.E.; Collins, M.T.; Alsheikh, S.; Sharaby, M.; Kirkpatrick, B.W. An across-Breed Genome Wide Association Analysis of Susceptibility to Paratuberculosis in Dairy Cattle. J. Dairy Res. 2017, 84, 61-67. [CrossRef] [PubMed]

30. Romdhane, B.R.; Beaunee, G.; Camanes, G.; Guatteo, R.; Fourichon, C.; Ezanno, P. Which Phenotypic Traits of Resistance Should Be Improved in Cattle to Control Paratuberculosis Dynamics in a Dairy Herd: A Modelling Approach. Vet. Res. 2017, 48, 62. [CrossRef] [PubMed]

31. Morris, C.A.; Hickey, S.M.; Henderson, H.V. The Effect of Johne's Disease on Production Traits in Romney, Merino and Merino X Romney-Cross Ewes. N. Z. Vet. J. 2006, 54, 204-209. [CrossRef] [PubMed]

32. Singh, P.K.; Singh, S.V.; Singh, M.K.; Saxena, V.K.; Horin, P.; Singh, A.V.; Sohal, J.S. Effect of Genetic Variation in the Mhc Class Ii Drb Region on Resistance and Susceptibility to Johne's Disease in Endangered Indian Jamunapari Goats. Int. J. Immunogenet. 2012, 39, 314-320. [CrossRef] [PubMed]

33. Begg, D.J.; Purdie, A.C.; de Silva, K.; Dhand, N.K.; Plain, K.M.; Whittington, R.J. Variation in Susceptibility of Different Breeds of Sheep to Mycobacterium avium Subspecies Paratuberculosis Following Experimental Inoculation. Vet. Res. 2017, 48, 36. [CrossRef]

34. Stewart, D.J.; Vaughan, J.A.; Stiles, P.L.; Noske, P.J.; Tizard, M.L.; Prowse, S.J.; Michalski, W.P.; Butler, K.L.; Jones, S.L. A Long-Term Bacteriological and Immunological Study in Holstein-Friesian Cattle Experimentally Infected with Mycobacterium avium Subsp. Paratuberculosis and Necropsy Culture Results for Holstein-Friesian Cattle, Merino Sheep and Angora Goats. Vet. Microbiol. 2007, 122, 83-96. [CrossRef] [PubMed]

35. Stabel, J.R.; Bannantine, J.P.; Hostetter, J.M. Comparison of Sheep, Goats, and Calves as Infection Models for Mycobacterium avium Subsp. Paratuberculosis. Vet. Immunol. Immunopathol. 2020, 225, 110060. [CrossRef] [PubMed]

36. Park, H.T.; Park, H.E.; Cho, Y.I.; Kim, E.H.; Jung, M.; Shin, S.W.; Lee, S.H.; Kim, D.Y.; Yoo, H.S. Potential Biomarkers as an Indicator of Vertical Transmission of Johne's Disease in a Korean Native Cattle Farm. J. Vet. Sci. 2017, 18, 343-349. [CrossRef] [PubMed]

37. Barrett, D.J.; Mee, J.F.; Mullowney, P.; Good, M.; McGrath, G.; Clegg, T.; More, S.J. Risk Factors Associated with Johne's Disease Test Status in Dairy Herds in Ireland. Vet. Rec. 2011, 168, 410. [CrossRef] [PubMed]

38. Clarke, C.J. The Pathology and Pathogenesis of Paratuberculosis in Ruminants and Other Species. J. Comp. Pathol. 1997, 116, 217-261. [CrossRef]

39. Whittington, R.J.; Sergeant, E.S. Progress Towards Understanding the Spread, Detection and Control of Mycobacterium avium Subsp Paratuberculosis in Animal Populations. Aust. Vet. J. 2001, 79, 267-278. [CrossRef] [PubMed]

40. Carrigan, M.J.; Seaman, J.T. The Pathology of Johne's Disease in Sheep. Aust. Vet. J. 1990, 67, 47-50. [CrossRef] [PubMed]

41. Jones, D.G.; Kay, J.M. Serum Biochemistry and the Diagnosis of Johne's Disease (Paratuberculosis) in Sheep. Vet. Rec. 1996, 139, 498-499. [CrossRef] [PubMed]

42. Bauman, C.A.; Jones-Bitton, A.; Menzies, P.; Toft, N.; Jansen, J.; Kelton, D. Prevalence Ofparatuberculosis in the Dairy Goat and Dairy Sheep Industries in Ontario. Can. Vet. J. 2016, 57, 169-175. [PubMed]

43. Kruze, J.; Salgado, M.; Paredes, E.; Mella, A.; Collins, M.T. Goat Paratuberculosis in Chile: First Isolation and Confirmation of Mycobacterium avium Subspecies Paratuberculosis Infection in a Dairy Goat. J. Vet. Diagn. Investig. 2006, 18, 476-479. [CrossRef] [PubMed]

44. Djønne, B. Paratuberculosis in Goats. In Paratuberculosis: Organism, Disease, Control; Behr, M.A., Collins, D.M., Eds.; CAB International: Oxfordshire, UK, 2010; pp. 169-178.

45. Stau, A.; Seelig, B.; Walter, D.; Schroeder, C.; Ganter, M. Seroprevalence of Mycobacterium avium Subsp. Paratuberculosis in Small Ruminants in Germany. Small Rumin. Res. 2012, 105, 361-365. [CrossRef]

46. Mercier, P.; Baudry, C.; Beaudeau, F.; Seegers, H.; Malher, X. Estimated Prevalence of Mycobacterium avium Subspecies Paratuberculosis Infection in Herds of Dairy Goats in France. Vet. Rec. 2010, 167, 412-415. [CrossRef] [PubMed]

47. Michel, A. Paratuberculosis in Sheep: An Emerging Disease in South Africa. Vet. Microbiol. 2000, 77, 299-307. [CrossRef]

48. Eamens, G.J.; Marsh, I.M.; Plain, K.M.; Whittington, R.J. Paratuberculosis (Johne's Disease). In Australian and New Zealand Standard Diagnostic Procedures; Department of Agriculture, Water and the Environment, Australian Government: Canberra, Australia, 2015; pp. 1-68.

49. Zhao, L.; Wang, Y.; Wang, J.L.; Zhao, W.H.; Cheng, H.X.; Ma, Y.M.; Chai, H.L.; Zhang, Z.S.; Wang, L.F.; Miao, Z.Q.; et al. Serological Investigation and Genotyping of Mycobacterium avium Subsp. Paratuberculosis in Sheep and Goats in Inner Mongolia, China. PLoS ONE 2021, 16, e0256628. [CrossRef] [PubMed]

50. Pithua, P.; Kollias, N.S. Estimated Prevalence of Caprine Paratuberculosis in Boer Goat Herds in Missouri, USA. Vet. Med. Int. 2012, 2012, 674085. [CrossRef] [PubMed]

51. Freitas; Diógenes, T.; de Azevedo, S.S.; Silva, M.L.C.R.; Júnior, F.G.; Santos, C.d.S.A.B.; Clementino, I.; Amaral, F.R.-C.; Alves, C.J. Epidemiological Characterization and Risk Factors Associated with Mycobacterium avium Subsp. Paratuberculosis Infection in Dairy Goats in the Brazilian Semiarid Region. Semin. Ciências Agrárias 2015, 36, 267. [CrossRef]

52. Debien, E.; Hélie, P.; Buczinski, S.; Lebœuf, A.; Bélanger, D.; Drolet, R. Proportional Mortality: A Study of 152 Goats Submitted for Necropsy from 13 Goat Herds in Quebec, with a Special Focus on Caseous Lymphadenitis. Can. Vet. J. 2013, 54, 581-587. [PubMed] 
53. Robbe-Austerman, S. Control of Paratuberculosis in Small Ruminants. Vet. Clin. N. Am. Food Anim. Pract. 2011, 27, 609-620. [CrossRef] [PubMed]

54. Abbas, B.; Idris, S.E.O.; Burhan, A. Isolation of M. Paratuberculosis from Goats in Sudan. Sudan J. Vet. Sci. Anim. Husb. 1986, $25,41-42$.

55. Benazzi, S.; el Hamidi, M.; Schliesser, T. Paratuberculosis in Sheep Flocks in Morocco: A Serological, Microscopical and Cultural Survey. Zent. Vet. B 1996, 43, 213-219. [CrossRef]

56. Elsohaby, I.; Fayez, M.; Alkafafy, M.; Refaat, M.; Al-Marri, T.; Alaql, F.A.; al Amer, A.S.; Abdallah, A.; Elmoslemany, A. Serological and Molecular Characterization of Mycobacterium avium Subsp. Paratuberculosis (Map) from Sheep, Goats, Cattle and Camels in the Eastern Province, Saudi Arabia. Animals 2021, 11, 323. [CrossRef] [PubMed]

57. Hailat, N.Q.; Hananeh, W.; Metekia, A.S.; Stabel, J.R.; Al-Majali, A.; Lafi, S. Pathology of Subclinical Paratuberculosis (Johne's Disease) in Awassi Sheep with Reference to Its Occurrence in Jordan. Veterinární Med. 2010, 55, 590-602. [CrossRef]

58. Selim, A.; Abdelhady, A.; Abdelrahman, A. Ovine Paratuberculosis: Seroprevalence and Comparison of Fecal Culture and Direct Fecal Pcr Assay. Comp. Immunol. Microbiol. Infect. Dis. 2021, 74, 101526. [CrossRef] [PubMed]

59. Fernandez-Silva, J.A.; Correa-Valencia, N.M.; Ramirez, N.F. Systematic Review of the Prevalence of Paratuberculosis in Cattle, Sheep, and Goats in Latin America and the Caribbean. Trop. Anim. Health Prod. 2014, 46, 1321-1340. [CrossRef] [PubMed]

60. Borujeni, P.M.; Hajikolaei, M.R.H.; Ghorbanpoor, M.; Sahar, H.E.; Bagheri, S.; Roveyshedzadeh, S. Comparison of Mycobacterium avium Subsp. Paratuberculosis Infection in Cattle, Sheep and Goats in the Khuzestan Province of Iran: Results of a Preliminary Survey. Vet. Med. Sci. 2021, 7, 1970-1979. [CrossRef] [PubMed]

61. Kumthekar, S.; Manning, E.J.; Ghosh, P.; Tiwari, K.; Sharma, R.N.; Hariharan, H. Mycobacterium avium Subspecies Paratuberculosis Confirmed Following Serological Surveillance of Small Ruminants in Grenada, West Indies. J. Vet. Diagn. Investig. 2013, 25, 527-530. [CrossRef] [PubMed]

62. Salgado, M.; Kruze, J.; Collins, M.T. Diagnosis of Paratuberculosis by Fecal Culture and Elisa on Milk and Serum Samples in Two Types of Chilean Dairy Goat Herds. J. Vet. Diagn. Investig. 2007, 19, 99-102. [CrossRef]

63. Mpenda, F.N.; Buza, J. Seroprevalence of Paratuberculosis in Goats and Sheep in Arusha, Northern Tanzania. Int. J. Sci. Res. 2014, 3, 2319-7064.

64. Martínez-Herrera, D.I.; Sarabia-Bueno, C.C.; Peniche-Cardeña, A.; Villagómez-Cortés, J.A.; Magdaleno-Méndez, A.; Ruíz, S.G.H.; Morales-Alvarez, J.F.; Flores-Castro, R. Seroepidemiology of Goat Paratuberculosis in Five Municipalities of Central Veracruz, Mexico. Trop. Subtrop. Agroecosyst. 2012, 15, 82-88.

65. Callejas-García, S.A. Estudio Epidemiológico De La Paratuberculosis Caprina En La Zona Centro Del Estado De Veracruz; Tesis Médico Veterinario Zootecnista, Universidad Veracruzana: Veracruz, Mexico, 2013.

66. Singh, K.; Chandel, B.S.; Dadawala, A.I.; Singh, S.V.; Chauhan, H.C.; Singh, B.; Agrawal, N.D.; Gupta, S.; Chaubey, K.K. Incidence of Mycobacterium avium Subspecies Paratuberculosis in Mehsana Breed of Goats from South Gujarat Using Multiple Tests. Adv. Anim. Vet. Sci. 2013, 1, s28-s31.

67. Kim, J.; Pham, L.; Jang, Y.; Kim, N.; Ryoo, S.; Jang, Y.; Jang, J.; Jung, S. Isolation and Characterization of Mycobacterium avium Subspecies Paratuberculosis in Korean Black Goat (Capra Hircus Aegagrus). Arch. Med. Vet. 2015, 47, 387-390. [CrossRef]

68. Julie, A.; Girard, C.; Dubreuil, P.; Daignault, D.; Galarneau, J.-R.; Boisclair, J.; Simard, C.; Bélanger, D. Prevalence of and Carcass Condemnation from Maedi-Visna, Paratuberculosis and Caseous Lymphadenitis in Culled Sheep from Quebec, Canada. Prev. Vet. Med. 2003, 59, 67-81.

69. Khbou, K.M.; Romdhane, R.; Sassi, L.; Amami, A.; Rekik, M.; Benzarti, M. Seroprevalence of Anti-Mycobacterium avium Subsp. Paratuberculosis Antibodies in Female Sheep in Tunisia. Vet. Med. Sci. 2020, 6, 393-398. [CrossRef]

70. Vidic, B.; Grgic, Z.; Jovicin, M.; Rasic, Z.; Savic, S.; Vidic, V.; Prica, N. Prevalence of Paratuberculosis Infection in Sheep. Vet. Glas. 2014, 68, 165-174. [CrossRef]

71. Rita, A.A.; Victor, N.N.; Silvia, P.; Luciana, P.; Anastasia, D.; Vincenzo, C. Ovine Paratuberculosis: A Seroprevalence Study in Dairy Flocks Reared in the Marche Region, Italy. Vet. Med. Int. 2011, $2011,782875$.

72. Coelho, A.C.; Pinto, M.L.; Silva, S.; Coelho, A.M.; Rodrigues, J.; Juste, R.A. Seroprevalence of Ovine Paratuberculosis Infection in the Northeast of Portugal. Small Rumin. Res. 2007, 71, 298-303. [CrossRef]

73. Sharma, S.; Gautam, A.; Singh, S.V.; Chaubey, K.K.; Mehta, R.; Gupta, S.; Sharma, M.; Rose, M.K.; Jain, V.K. Prevalence of Mycobacterium avium Subspecies Paratuberculosis (Map) Infection in Suspected Diarrhoeic Buffaloes and Cattle Reporting at Veterinary University in India. Comp. Immunol. Microbiol. Infect. Dis. 2020, 73, 101533. [CrossRef] [PubMed]

74. Lambeth, C.; Reddacliff, L.A.; Windsor, P.; Abbott, K.A.; McGregor, H.; Whittington, R.J. Intrauterine and Transmammary Transmission of Mycobacterium avium Subsp Paratuberculosis in Sheep. Aust. Vet. J. 2004, 82, 504-508. [CrossRef]

75. Henderson, D.C.; Caldow, G.; Low, C.J. Paratuberculosis in Cattle: Pathology and Clinical Disease. In Assessment of Surveillance and Control of Johne's Disease in Farm Animals in GB; Scottish Agricultural College, Veterinary Science Division: Edinburgh, UK, 2000; pp. 15-19.

76. Milner, A.R.; Wendy, N.; Mack, K.J.; Coates, J.H.; Ian, G.; Sheldrick, P. The Sensitivity and Specificity of a Modified Elisa for the Diagnosis of Johne's Disease from a Field Trial in Cattle. Vet. Microbiol. 1990, 25, 193-198.

77. Clarke, C.J.; Little, D. The Pathology of Ovine Paratuberculosis: Gross and Histological Changes in the Intestine and Other Tissues. J. Comp. Pathol. 1996, 114, 419-437. [CrossRef] 
78. Corpa, J.M.; Garrido, J.; Marin, J.F.G.; Perez, V. Classification of Lesions Observed in Natural Cases of Paratuberculosis in Goats. J. Comp. Pathol. 2000, 122, 255-265. [CrossRef]

79. Kreeger, J.M. Ruminant Paratuberculosis-A Century of Progress and Frustration. J. Vet. Diagn. Investig. 1991, 3, 373-382. [CrossRef] [PubMed]

80. Pérez, V.; Marín, J.F.G.; Badiola, J.J. Description and Classification of Different Types of Lesion Associated with Natural Paratuberculosis Infection in Sheep. J. Comp. Pathol. 1996, 114, 107-122. [CrossRef]

81. Catton, B.A. Paucibacillary Paratuberculosis in a Goat. Can. Vet. J. 2002, 43, 787-788.

82. Sikandar, A.; Cheema, A.H.; Adil, M.; Younus, M.; Zaneb, H.; Zaman, M.A.; Masood, S. Ovine Paratuberculosis-a Histopathological Study from Pakistan. J. Anim. Plant Sci. 2013, 23, 749-753.

83. Chaturvedi, S.; Singh, S.V.; Srivastava, A.K.; Gangwar, N.K.; Kumar, N.; Rawat, K.D.; Dhama, K. Comparative Evaluation of Fat, Is900 Pcr and Microscopy Vis a Vis Histo-Pathology for the Detection of Mycobacterium avium Subsp Paratuberculosis Infection in Tissues of Goats Naturally Died in Herds Endemic for Johne's Disease. Indian J. Anim. Sci. 2017, 87, 685-693.

84. Srikanth, M.; Narayanaswamy, H.D.; Satyanarayana, M.L.; Suguna, R.A.O.; Rathnamma, D.; Ranganath, L.; Mukurtal, S.Y.; Sarvesha, K.; Manjunatha, S.S. Pathomorphological Studies on Ovine Paratuberculosis in An Organised Sheep Farm in Karnataka. J. Cell Tissue Res. 2017, 17, 6067-6072.

85. Hamid, M.A.; Mohammed, G.E.E.; Bakheit, A.O.; Saeed, E.M.A. Histopathological and RT-PCR Detection of Mycobacterium Paratuberculosis in Tissues of Clinically Suspected Small Ruminants. Int. J. Life Sci. Sci. Res. 2018, 4, $2012-2018$.

86. Stehman, S.M. Paratuberculosis in Small Ruminants, Deer, and South American Camelids. Vet. Clin. N. Am. Food Anim. Pract. 1996, 12, 441-455. [CrossRef]

87. Coelho, A.C.; Coelho, A.M.; GarcÍA-Diez, J.; Pires, M.A.; Pinto, M.L. Detection of Mycobacterium avium Subsp. Paratuberculosis by Several Diagnostics Techniques in Clinical Suspected Sheep. J. Hell. Vet. Med. Soc. 2018, 68, 167. [CrossRef]

88. Shulaw, W.P.; Bech-Nielsen, S.; Rings, D.M.; Getzy, D.M.; Woodruff, T.S. Serodiagnosis of Paratuberculosis in Sheep by Use of Agar Gel Immunodiffusion. Am. J. Vet. Res. 1993, 54, 13-19. [PubMed]

89. Derakhshandeh, A.; Namazi, F.; Khatamsaz, E.; Eraghi, V.; Hemati, Z. Goat Paratuberculosis in Shiraz: Histopathological and Molecular Approaches. Vet. Res. Forum 2018, 9, 253-257. [PubMed]

90. Thakur, M.; Madhulina, M.; Shweta, S.; Vipan, K.G. Comparative Evaluation of Different Diagnostic Techniques for Detection of Naturally Occurring Paratuberculosis in Gaddi Goats. Small Rumin. Res. 2019, 174, 92-98. [CrossRef]

91. Greig, A. Johne's Disease in Sheep and Goats. In Practice 2000, 22, 146-151. [CrossRef]

92. Marin, G.J.F.; Chavez, G.; Ajuriz, J.J. Prevalence of Paratuberculosis in Infected Goat Flocks and Comparison of Different Methods of Diagnosis. In Proceedings of the Third International Colloquium on Paratuberculosis, Orlando, FL, USA, 28 September-2 October 1991.

93. Kawaji, S.; Taylor, D.L.; Mori, Y.; Whittington, R.J. Detection of Mycobacterium avium Subsp. Paratuberculosis in Ovine Faeces by Direct Quantitative Pcr Has Similar or Greater Sensitivity Compared to Radiometric Culture. Vet. Microbiol. 2007, 125, 36-48. [CrossRef] [PubMed]

94. Chaubey, K.K.; Gupta, R.D.; Gupta, S.; Singh, S.V.; Bhatia, A.K.; Jayaraman, S.; Kumar, N.; Goel, A.; Rathore, A.S.; Sahzad; et al. Trends and Advances in the Diagnosis and Control of Paratuberculosis in Domestic Livestock. Vet. Q. 2016, 36, 203-227. [CrossRef]

95. Buergelt, C.D.; Ginn, P.E. The Histopathologic Diagnosis of Subclinical Johne's Disease in N. American Bison (Bison Bison). Vet. Microbiol. 2000, 77, 325-331. [CrossRef]

96. Whittington, R.J.; Begg, D.J.; de Silva, K.; Purdie, A.C.; Dhand, N.K.; Plain, K.M. Case Definition Terminology for Paratuberculosis (Johne's Disease). BMC Vet. Res. 2017, 13, 328. [CrossRef] [PubMed]

97. Nielsen, S.S.; Toft, N. Ante Mortem Diagnosis of Paratuberculosis: A Review of Accuracies of Elisa, Interferon-Gamma Assay and Faecal Culture Techniques. Vet. Microbiol. 2008, 129, 217-235. [CrossRef]

98. Hosseiniporgham, S.; Cubeddu, T.; Rocca, S.; Sechi, L.A. Identification of Mycobacterium avium Subsp. Paratuberculosis (Map) in Sheep Milk, a Zoonotic Problem. Microorganisms 2020, 8, 1264. [CrossRef]

99. OIE. Principles and Methods of Validation of Diagnostic Assays for Infectious. In Manual of Diagnstic Tests and Vaccines for Terrestrial Animals; World Organization for Animal Health: Paris, France, 2018; pp. 72-87.

100. Manning, E.J.B.; Collins, M.T. Mycobacterium avium Subsp. Paratuberculosis: Pathogen, Pathogenesis and Diagnosis. Rev. Sci. Tech. 2001, 20, 133-150. [CrossRef]

101. Butot, S.; Ricchi, M.; Sevilla, I.A.; Michot, L.; Molina, E.; Tello, M.; Russo, S.; Arrigoni, N.; Garrido, J.M.; Tomas, D. Estimation of Performance Characteristics of Analytical Methods for Mycobacterium avium Subsp. Paratuberculosis Detection in Dairy Products. Front. Microbiol. 2019, 10, 509. [CrossRef]

102. Pavlik, I. Parallel Faecal and Organ Mycobacterium avium Subsp. Paratuberculosis Culture of Different Productivity Types of Cattle. Vet. Microbiol. 2000, 77, 309-324. [CrossRef]

103. Reddacliff, L.A.; Whittington, R.J. Experimental Infection of Weaner Sheep with S Strain Mycobacterium avium Subsp. Paratuberculosis. Vet. Microbiol. 2003, 96, 247-258. [CrossRef] [PubMed]

104. Whittington, R.J.; Marsh, I.; Turner, M.J.; McAllister, S.; Choy, E.; Eamens, G.J.; Marshall, D.J.; Ottaway, S. Rapid Detection of Mycobacterium Paratuberculosis in Clinical Samples from Ruminants and in Spiked Environmental Samples by Modified Bactec 12b Radiometric Culture and Direct Confirmation by Is900 Pcr. J. Clin. Microbiol. 1998, 36, 701-707. [CrossRef] [PubMed] 
105. Whittington, R.J.; Marsh, I.; McAllister, S.; Turner, M.J.; Marshall, D.J.; Fraser, C.A. Evaluation of Modified Bactec 12b Radiometric Medium and Solid Media for Culture of Mycobacterium avium Subsp. Paratuberculosis from Sheep. J. Clin. Microbiol. 1999, 37, 1077-1083. [CrossRef] [PubMed]

106. de Juan, L.; Alvarez, J.; Aranaz, A.; Rodriguez, A.; Romero, B.; Bezos, J.; Mateos, A.; Dominguez, L. Molecular Epidemiology of Types I/Iii Strains of Mycobacterium avium Subspecies Paratuberculosis Isolated from Goats and Cattle. Vet. Microbiol. 2006, 115, 102-110. [CrossRef] [PubMed]

107. Sonawane, G.G.; Tripathi, B.N. Comparative Evaluation of Diagnostic Tests for the Detection of Mycobacterium avium Subsp. Paratuberculosis in the Tissues of Sheep Affected with Distinct Pathology of Paratuberculosis. Int. J. Mycobacteriol. 2016, 5, S88-S89. [CrossRef]

108. Ibrahim, A.; El Sanousi, S.; Aradaib, I. Detection of Mycobacterium avium Subspecies Paratuberculosis Using Nested Polymerase Chain Reaction (Npcr). Veterinarski Arhiv. 2004, 74, 27-35.

109. Rachlin, J.; Ding, C.; Cantor, C.; Kasif, S. Computational Tradeoffs in Multiplex Pcr Assay Design for Snp Genotyping. BMC Genom. 2005, 6, 102. [CrossRef] [PubMed]

110. Rajeev, S.; Zhang, Y.; Sreevatsan, S.; Motiwala, A.S.; Byrum, B. Evaluation of Multiple Genomic Targets for Identification and Confirmation of Mycobacterium avium Subsp. Paratuberculosis Isolates Using Real-Time Pcr. Vet. Microbiol. 2005, 105, $215-221$. [CrossRef] [PubMed]

111. Stephan, R.; Schumacher, S.; Tasara, T.; Grant, I.R. Prevalence of Mycobacterium avium Subspecies Paratuberculosis in Swiss Raw Milk Cheeses Collected at the Retail Level. J. Dairy Sci. 2007, 90, 3590-3595. [CrossRef] [PubMed]

112. Slana, I.; Paolicchi, F.; Janstova, B.; Navratilova, P.; Pavlik, I. Detection Methods for Mycobacterium avium Subsp Paratuberculosis in Milk and Milk Products: A Review. Veterinární Med. 2008, 53, 283-306. [CrossRef]

113. Sange, M.D.; Becker, A.; Hassan, A.A.; Bulte, M.; Ganter, M.; Siebert, U.; Abdulmawjood, A. Development and Validation of a Loop-Mediated Isothermal Amplification Assay-A Rapid and Sensitive Detection Tool for Mycobacterium avium Subsp. Paratuberculosis in Small Ruminants. J. Appl. Microbiol. 2019, 127, 47-58. [CrossRef] [PubMed]

114. Sevilla, I.; Singh, S.V.; Garrido, J.M.; Aduriz, G.; Rodriguez, S.; Geijo, M.V.; Whittington, R.J.; Saunders, V.; Whitlock, R.H.; Juste, R.A. Pcr-Rea Genotype of Paratuberculosis Strains Isolated from Different Host Species and Geographical Locations. Rev. Sci. Tech. 2005, 24, 1061-1066. [CrossRef] [PubMed]

115. Whittington, R.J.; Eamens, G.J.; Cousins, D.V. Specificity of Absorbed Elisa and Agar Gel Immuno-Diffusion Tests for Paratuberculosis in Goats with Observations About Use of These Tests in Infected Goats. Aust. Vet. J. 2003, 81, 71-75. [CrossRef]

116. Kumar, V.; Bhatia, A.K.; Singh, S.V. Evaluation of Efficacy of the Species Specific Antigens in the Diagnosis of Ovine and Caprine Paratuberculosis Using Plate Elisa. J. Immunol. Immunopathol. 2006, 8, 48-53.

117. Singh, S.V.; Singh, A.V.; Singh, P.K.; Sohal, J.S.; Singh, N.P. Evaluation of an Indigenous Elisa for Diagnosis of Johne's Disease and Its Comparison with Commercial Kits. Indian J. Microbiol. 2007, 47, 251-258. [CrossRef] [PubMed]

118. Hope, A.F.; Kluver, P.F.; Jones, S.L.; Condron, R.J. Sensitivity and Specificity of Two Serological Tests for the Detection of Ovine Paratuberculosis. Aust. Vet. J. 2000, 78, 850-856. [CrossRef] [PubMed]

119. Gwozdz, J.M.; Thompson, K.G.; Manktelow, B.W.; Murray, A.; West, D.M. Vaccination against Paratuberculosis of Lambs Already Infected Experimentally with Mycobacterium avium Subspecies Paratuberculosis. Aust. Vet. J. 2000, 78, 560-566. [CrossRef] [PubMed]

120. Sergeant, E.S.; Marshall, D.J.; Eamens, G.J.; Kearns, C.; Whittington, R.J. Evaluation of an Absorbed Elisa and an Agar-Gel Immuno-Diffusion Test for Ovine Paratuberculosis in Sheep in Australia. Prev. Vet. Med. 2003, 61, 235-248. [CrossRef]

121. Robbe-Austerman, S.; Gardner, I.A.; Thomsen, B.V.; Morrical, D.G.; Martin, B.M.; Palmer, M.V.; Thoen, C.O.; Ewing, C. Sensitivity and Specificity of the Agar-Gel-Immunodiffusion Test, Elisa and the Skin Test for Detection of Paratuberculosis in United States Midwest Sheep Populations. Vet. Res. 2006, 37, 553-564. [CrossRef] [PubMed]

122. Alvarez, I.; Cipolini, F.; Wigdorovitz, A.; Trono, K.; Barrandeguy, M.E. The Efficacy of Elisa Commercial Kits for the Screening of Equine Infectious Anemia Virus Infection. Rev. Argent. Microbiol. 2015, 47, 25-28. [CrossRef] [PubMed]

123. Kaba, J.; Gerlach, G.F.; Nowicki, M.; Rypuła, K. Agreement between Elisa and Complement Fixation Test Used for Diagnosing of Paratuberculosis in Goats. Pol. J. Vet. Sci. 2008, 11, 209-212. [PubMed]

124. Maroudam, V.; Subramanian, B.M.; Kumar, P.P.; Raj, G.D. Paratuberculosis: Diagnostic Methods and Their Constraints. J. Vet. Sci. Technol. 2015, 6, 4172 .

125. Sherman, D.M.; Gay, J.M.; Bouley, D.S.; Nelson, G.H. Comparison of the Complement-Fixation and Agar Gel Immunodiffusion Tests for Diagnosis of Subclinical Bovine Paratuberculosis. Am. J. Vet. Res. 1990, 51, 461-465.

126. Sockett, D.C.; Conrad, T.A.; Thomas, C.B.; Collins, M.T. Evaluation of Four Serological Tests for Bovine Paratuberculosis. J. Clin. Microbiol. 1992, 30, 1134-1139. [CrossRef]

127. Reichel, M.P.; Kittelberger, R.; Penrose, M.E.; Meynell, R.M.; Cousins, D.; Ellis, T.; Mutharia, L.M.; Sugden, E.A.; Johns, A.H.; de Lisle, G.W. Comparison of Serological Tests and Faecal Culture for the Detection of Mycobacterium avium Subsp. Paratuberculosis Infection in Cattle and Analysis of the Antigens Involved. Vet. Microbiol. 1999, 66, 135-150. [CrossRef]

128. Singh, S.V.; Singh, A.V.; Singh, R.; Sandhu, K.S.; Gupta, V.K. Survey of Ruminant Population of Northern India for the Incidence of Mycobacterium avium Subsp. Paratuberculosis Infection. In Proceedings of the Eighth International Colloquium on Paratuberculosis, Denmark, Copenhagen, 14-17 August 2005. 
129. Kalis, C.H.; Barkema, H.W.; Hesselink, J.W.; van Maanen, C.; Collins, M.T. Evaluation of Two Absorbed Enzyme-Linked Immunosorbent Assays and a Complement Fixation Test as Replacements for Fecal Culture in the Detection of Cows Shedding Mycobacterium avium Subspecies Paratuberculosis. J. Vet. Diagn. Investig. 2002, 14, 219-224. [CrossRef]

130. Barad, D.B.; Chandel, B.S.; Dadawala, A.I.; Chauhan, H.C.; Kher, H.S.; Shroff, S.; Bhagat, A.G.; Singh, S.V.; Singh, P.K.; Singh, A.V.; et al. Incidence of Mycobacterium avium Subspecies Paratuberculosis in Mehsani and Surti Goats of Indian Origin Using Multiple Diagnostic Tests. J. Biol. Sci. 2014, 14, 124-133. [CrossRef]

131. Mukartal, S.Y.; Rathnamma, D.; Narayanaswamy, H.D.; Isloor, S.; Singh, S.V.; Chandranaik, B.M.; Shambanna, M.S. Prevalence of Ovine Johne's Disease in Bannur Breed of Sheep in Organized Farm Using Multiple Diagnostic Tests. Adv. Anim. Vet. Sci. 2016, 4, 506-512. [CrossRef]

132. Biswal, S.; Rath, A.P.; Singh, S.V.; Sahoo, N. Detection of Mycobacterium avium Subsp. Paratuberculosis. Indian J. Anim. Res. 2020, 54, 709-715.

133. Bastida, F.; Juste, R.A. Paratuberculosis Control: A Review with a Focus on Vaccination. J. Immune Based Ther. Vaccines 2011, $9,8$. [CrossRef] [PubMed]

134. Gupta, S.; Singh, S.V.; Singh, M.; Chaubey, K.K.; Karthik, K.; Bhatia, A.K.; Kumar, N.; Dhama, K. Vaccine Approaches for the 'Therapeutic Management' of Mycobacterium avium Subspecies Paratuberculosis Infection in Domestic Livestock. Vet. Q. 2019, 39, 143-152. [CrossRef] [PubMed]

135. Sweeney, R.W. Transmission of Paratuberculosis. Vet. Clin. N. Am. Food Anim. Pract. 1996, 12, 305-312. [CrossRef]

136. Windsor, P.A.; Whittington, R.J. Evidence for Age Susceptibility of Cattle to Johne's Disease. Vet. J. 2010, 184, 37-44. [CrossRef]

137. Windsor, C.; Jääskelä, J.P.; Finlay, R. Housing Wealth Effects: Evidence from an Australian Panel. Economica 2015, 82, 552-577. [CrossRef]

138. Kudahl, A.B.; Sorensen, J.T.; Nielsen, S.S.; Ostergaard, S. Simulated Economic Effects of Improving the Sensitivity of a Diagnostic Test in Paratuberculosis Control. Prev. Vet. Med. 2007, 78, 118-129. [CrossRef] [PubMed]

139. Dorshorst, N.C.; Collins, M.T.; Lombard, J.E. Decision Analysis Model for Paratuberculosis Control in Commercial Dairy Herds. Prev. Vet. Med. 2006, 75, 92-122. [CrossRef] [PubMed]

140. Kirkeby, C.; Graesboll, K.; Nielsen, S.S.; Christiansen, L.E.; Toft, N.; Halasa, T. Adaptive Test Schemes for Control of Paratuberculosis in Dairy Cows. PLoS ONE 2016, 11, e0167219. [CrossRef]

141. Reddacliff, L.; Eppleston, J.; Windsor, P.; Whittington, R.; Jones, S. Efficacy of a Killed Vaccine for the Control of Paratuberculosis in Australian Sheep Flocks. Vet. Microbiol. 2006, 115, 77-90. [CrossRef] [PubMed]

142. Fridriksdottir, V. Paratuberculosis in Iceland: Epidemiology and Control Measures, Past and Present. Vet. Microbiol. 2000, 77, 263-267. [CrossRef]

143. Windsor, P.A. Understanding the Efficacy of Vaccination in Controlling Ovine Paratuberculosis. Small Rumin. Res. 2013, 110, 161-164. [CrossRef]

144. Serrano, M.; Elguezabal, N.; Sevilla, I.A.; Geijo, M.V.; Molina, E.; Arrazuria, R.; Urkitza, A.; Jones, G.J.; Vordermeier, M.; Garrido, J.M.; et al. Tuberculosis Detection in Paratuberculosis Vaccinated Calves: New Alternatives against Interference. PLoS ONE 2017, 12, e0169735.

145. Dhand, N.K.; Eppleston, J.; Whittington, R.J.; Windsor, P.A. Changes in Prevalence of Ovine Paratuberculosis Following Vaccination with Gudair(R): Results of a Longitudinal Study Conducted over a Decade. Vaccine 2016, 34, 5107-5113. [CrossRef] [PubMed]

146. Gautam, M.; Anderson, P.; Ridler, A.; Wilson, P.; Heuer, C. Economic Cost of Ovine Johne's Disease in Clinically Affected New Zealand Flocks and Benefit-Cost of Vaccination. Vet. Sci. 2018, 5, 16. [CrossRef]

147. Espinosa, J.; Fernandez, M.; Royo, M.; Grau, A.; Collazos, J.A.; Benavides, J.; Ferreras, M.d.; Minguez, O.; Perez, V. Influence of Vaccination against Paratuberculosis on the Diagnosis of Caprine Tuberculosis During Official Eradication Programmes in Castilla Y Leon (Spain). Transbound. Emerg. Dis. 2021, 68, 692-703. [CrossRef]

148. Singh, S.V.; Saurabh, G.; Chaubey, K.K.; Saket, B.; Rawat, K.D.; Naveen, K.; Tiwari, H.A.; Vinay, C.; Sohal, J.S.; Kuldeep, D.; et al. 'Therapeutic Management' of Incurable Paratuberculosis Using 'indigenous Vaccine' in Goatherds, Endemically Infected with Johne's Disease. Int. J. Pharmacol. 2017, 13, 145-155. [CrossRef]

149. Luttikholt, S.; Lievaart-Peterson, K.; Gonggrijp, M.; Aalberts, M.; van Schaik, G.; Vellema, P. Mycobacterium avium Subsp. Paratuberculosis Elisa Responses in Milk Samples from Vaccinated and Nonvaccinated Dairy Goat Herds in The Netherlands. Vet. Sci. 2019, 6, 58. [CrossRef] [PubMed]

150. Windsor, P. Research into Vaccination against Ovine Johne's Disease in Australia. Small Rumin. Res. 2006, 62, 139-142.

151. Reddacliff, L.A. Field Evaluation of Ojd Control Using Gudair; Meat and Livestock Australia Ltd.: North Sydney, Australia, 2005.

152. Koets, A.; Hoek, A.; Langelaar, M.; Overdijk, M.; Santema, W.; Franken, P.; Eden, W.; Rutten, V. Mycobacterial 70 Kd Heat-Shock Protein Is an Effective Subunit Vaccine against Bovine Paratuberculosis. Vaccine 2006, 24, 2550-2559. [CrossRef] [PubMed]

153. Roupie, V.; Leroy, B.; Rosseels, V.; Piersoel, V.N.-G.I.; Romano, M.; Huygen, K. Immunogenicity and Protective Efficacy of DNA Vaccines Encoding Map0586c and Map4308c of Mycobacterium avium Subsp. Paratuberculosis Secretome. Vaccine 2008, 26, 4783-4794. [CrossRef] [PubMed]

154. Juste, R.A.; Garrido, J.M.; Elguezabal, N.; Sevilla, I.A. Paratuberculosis Vaccines and Vaccination. In Paratuberculosis: Organism, Disease, Control; Marcel, A., Behr, M.A., Stevenson, K., Kapur, K., Eds.; CABI International: Wallingford, UK, 2020 ; pp. 365-379. 
155. Pant, S.D.; Schenkel, F.S.; Verschoor, C.P.; You, Q.; Kelton, D.F.; Moore, S.S.; Karrow, N.A. A Principal Component Regression Based Genome Wide Analysis Approach Reveals the Presence of a Novel Qtl on Bta7 for Map Resistance in Holstein Cattle. Genomics 2010, 95, 176-182. [CrossRef] [PubMed]

156. Kirkpatrick, B.W.; Shook, G.E. Genetic Susceptibility to Paratuberculosis. Vet. Clin. N. Am. Food Anim. Pract. $2011,27,559-571$. [CrossRef] [PubMed] 